\title{
BODY COMPOSITION OF MALE OFFICE WORKERS COMPARED BY MEANS OF INFRARED REFLECTION MEASUREMENT, BIOIMPEDANCE ANALYSIS AND CALIPERMETRY
}

\author{
Christoph Raschka ${ }^{1}$, O-Sung Kwon ${ }^{1}$, Horst J. Koch $^{2}$ \\ ${ }^{1}$ Institute of Sports Sciences, Julius Maximilian University, Würzburg, Germany \\ ${ }^{2}$ Heinrich-Braun-Klinikum, Zwickau, Germany
}

\begin{abstract}
There are currently many different anthropometric methods to determine individual body fat percentage, as well as almost as many variants of bioelectric impedance analysis (BIA) and only a single method of infrared reflection measurement (IR) as easily feasible methods of field research. The present study aims at a simultaneous comparison between calipermetry, IR and BIA. In particular, the question which measurement method could be used as an equivalent method in the event of failure of the BIA or IR is investigated. The sample group consisted of 250 male office workers from the Rhine-Main area (average age $31.75 \pm 9.16$ years, average height $178.5 \pm 6.93 \mathrm{~cm}$ and average weight $80.61 \pm 9.42 \mathrm{~kg}$ ). The measurements were previously scheduled and mostly carried out during the lunch break. For anthropometry, 13 skin fat folds were measured with the help of the Accu ${ }^{\oplus}$ Measure Caliper, thigh circumference with the help of a measuring tape, height with a height measuring device and body mass on the weight scale. Subsequently, an IR measurement $\left(\right.$ Futrex $\left.^{\oplus}\right)$ and a BIA $\left(\right.$ InBody $\left.^{\oplus}\right)$ were performed on the same subject. The parameters of body fat percentage and total body water (in litres) were examined. The statistical methods were correlation coefficients, BlandAltman comparison and paired $t$-test for equivalence. For the men studied, the highest correlation coefficients were in the comparisons between the formulas according to Parízkova \& Buzkova 1 and Parízkova \& Buzkova 3 ( $\mathrm{r}=0.93)$, as well as for Parízkova \& Buzkova 3 and Parízkova \& Buzkova $4(\mathrm{r}=0.96)$. The correlation coefficient for the IR vs. BIA comparison was only $r=0.56$. A key result of the present study was the finding that certain
\end{abstract}


methods cannot be substituted in an equivalent way, in fact only some calipermetric regression equations.

Keywords: percentage of body fat; bioimpedance analysis; calipermetry; infrared reflection measurement; body composition

\section{INTRODUCTION}

In sports medicine, anthropology, general medicine and internal practice, bioimpedance analysis (BIA), infrared reflection measurement and calipermetry measurement have been used for years to determine body composition for reasons of practicality, cost-benefit ratio and minimisation of potential damage to patients.

The latter anthropometric method is an indirect field method by which body values, such as total body fat and fat-free mass can be determined on the basis of a two-compartment model. Depending on the regression equation used, at least three to 14 measuring points are defined on the body $[13,14,18]$. With the help of different regression equations and additional parameters, such as age, gender, body height and body weight, the total body fat and the fat-free mass can be calculated. The gripping and lifting of the skin fat fold is done by lifting a double layer, consisting of skin and subcutaneous adipose tissue, from the muscles. With a standardized calliper $[9,10,13,14]$ a constant pressure of $10 \mathrm{~g} / \mathrm{mm}^{2}$ is exerted.

Infrared reflection measurement takes advantage of the different effects of infrared light rays on the individual tissues. Some of the continuous radiation is absorbed by adipose tissue and the other part is reflected by the fat-free mass. Statistical comparison with densitometry has shown that the measurements on the biceps of the dominant arm provide sufficient correlation values [8].

Bioelectric impedance analysis is a relatively easy-to-use and safe measurement method for detecting a person's body composition. The basis is the fact that different tissue and cell types of the human body conduct electrical current well. The impedance consists of resistance and reactance. The non-cellularly bound bodily fluid behaves like an electrical conductor that counteracts the current with a simple Ohm's resistance called Resistance (R). Reactance (Xc) is the capacitive resistance caused by the capacitor properties of the body cells. The resistance value (resistance of body water) calculates the total body water using the impedance index. By determining the total body water, the fat-free mass is calculated. Here, the total body water (TBW) is divided by the factor 0.732 , since it is assumed that about $73 \%$ of the fat-free mass consists of body 
water [7]. The body fat mass can be calculated by subtracting the fat-free mass from the total body weight.

The aim of the present study is to compare the values obtained in the context of a body composition analysis by the measurement methods of calipermetry, infrared reflection measurement (IR) and bioelectrical impedance analysis (BIA) and to assess to what extent the results of the measurement methods used correlate with each other. The focus is on the percentage of body fat and the total body water (in litres).

\section{METHODOLOGY}

A total of 250 men took part in the study. At the time of the study, the subjects were between 16 and 59 years old. The subjects were recruited from the area of Frankfurt am Main, Offenbach am Main and Darmstadt (Hesse, Germany).

The InBody ${ }^{\circ} 230$ was used for bioelectric impedance analysis. The $\mathrm{Accu}^{\circ}$ measure from the manufacturer AuccFitness was used as a calliper.

Various regression equations were used to determine the fat content (Möhr \& Johnsen [11], Parízková \& Buzková 1 [12], Parízková \& Buzková 2 [12], Parízková \& Buzková 3 [12], Parízková \& Buzková 4 [12], Weltman \& Katch [19], Rathbun et al. [16], Ball et al. [1]). In order to calculate the percentage of body fat according to Rathbun et al. [16], one still needs the specific weight [4].

The measurement with the FUTREX Body Fat Analyzer 6100/XL takes place in a sitting position. With the help of the "elbowmeter", the exact location of the measuring point is determined. Light absorption is the decisive factor for determining the body fat percentage. The measurement takes about one minute.

The bioelectric impedance analysis was carried out with the help of the InBody ${ }^{\otimes} 230$ by Biospace. The technology is based on segmental multifrequency measurement with tetrapolar 8-electrode technology. The analysis with the InBody 230 is performed standing.

In addition to Pearson's correlation coefficient, Bland-Altman analysis [2, 3 ] was used for the statistics, with which the two methods applied in the same experimental group are compared. In the Bland-Altman plot, the difference $(\mathrm{di}=\mathrm{Xi}-\mathrm{Yi})$ is plotted on the ordinate against the mean $(\mathrm{MW}=(\mathrm{Xi}-\mathrm{Yi}) / 2)$ on the abscissa. In addition to Bland-Altman analysis, the paired t-test for equivalence was used. Commercial statistical programs such as EViews 6\&7 of quantitative micro software, WisStat of the Company of Fitch and NCSS version 12 were used for the preparation of the measured values. 


\section{RESULTS}

A total of 250 men from different age groups were examined. The frequency distribution of the age structure of the group of subjects showed that the largest proportion (24.4\%) of men was between 30 and 34 years of age. The average age of the men was 31.8 years, their average weight $80.6 \mathrm{~kg}$ and average height $178.6 \mathrm{~cm}$. A comparison of the individual measurements of the men showed that all averages ranged from $12.0 \%$ to $14.6 \%$. Only the formula according to Weltman \& Katch had a much higher average of $25.2 \%$. In detail, the following averages with standard deviation were found:

Table 1. Averages of body fat percentage

\begin{tabular}{lcc}
\hline \% body fat & mean & standard deviation \\
\hline Möhr \& Johnson [11] & 13.9 & 3.3 \\
\hline Parízková \& Buzková 1 [12] & 13.6 & 2.4 \\
\hline Parízková \& Buzková 2[12] & 12.0 & 4.5 \\
\hline Parízková \& Buzková 3 [12] & 13.8 & 4.6 \\
\hline Parízková \& Buzková 4 [12] & 12.6 & 4.5 \\
\hline Weltman \& Katch [19] & 12.0 & 4.4 \\
\hline Rathbun et al. [16] & 25.2 & 6.0 \\
\hline Ball et al. [1] & 12.7 & 5.2 \\
\hline
\end{tabular}

One possible explanation for the large mean difference in the calculation according to Weltman \& Katch [19] could be that the formula is based on the total body weight and the thigh circumference.

A Bland-Altman plot was created for calipermetry only if the compared regression equations had at least one correlation coefficient above 0.8 . An additional $t$-test was performed to check the equivalence.

First and foremost, the Bland-Altman plot shows that all but two subjects were within the confidence limit (95\% confidence interval). The correlation coefficient is $\mathrm{r}=0.80$. The additional $t$-test of equivalence gives a $\mathrm{p}$-value of 0.01 . Thus, equivalence is assumed (Fig. 1). 


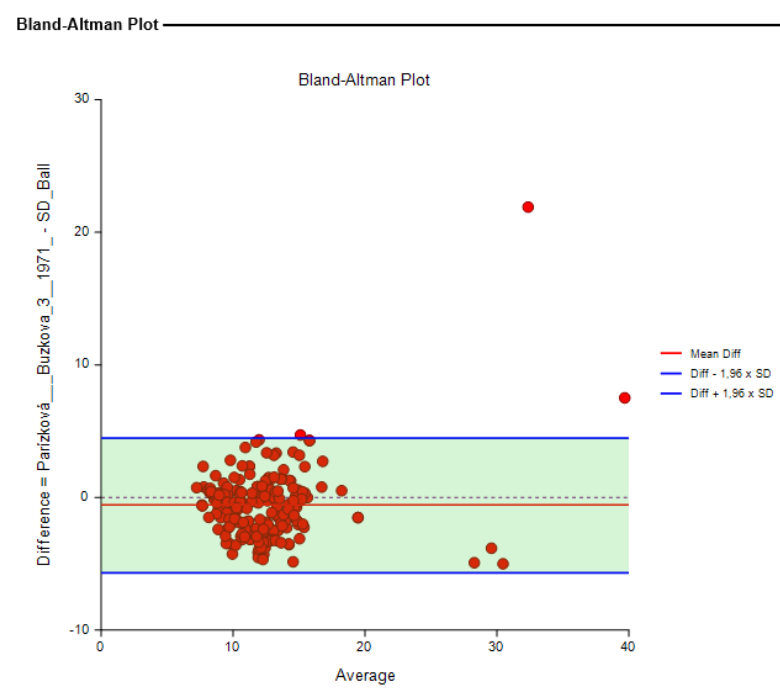

Figure 1. Bland-Altman Plot, Parízková \& Buzková 3 vs. Ball et al.

When comparing the regression equations according to Parízková \& Buzková 1 with Ball et al., the additional $t$-test for testing equivalence results in a $\mathrm{p}$-value of 0.97 . Thus, equivalence is not assumed (Fig. 2).

In the Bland-Altman plot, the vast majority of points are within the confidence limit, compared to the regression equations according to Parízková \& Buzková 2 with Ball et al. The $t$-test for equivalence gives a $\mathrm{p}$-value of 0.00 . Thus, equivalence is assumed (Fig. 3).

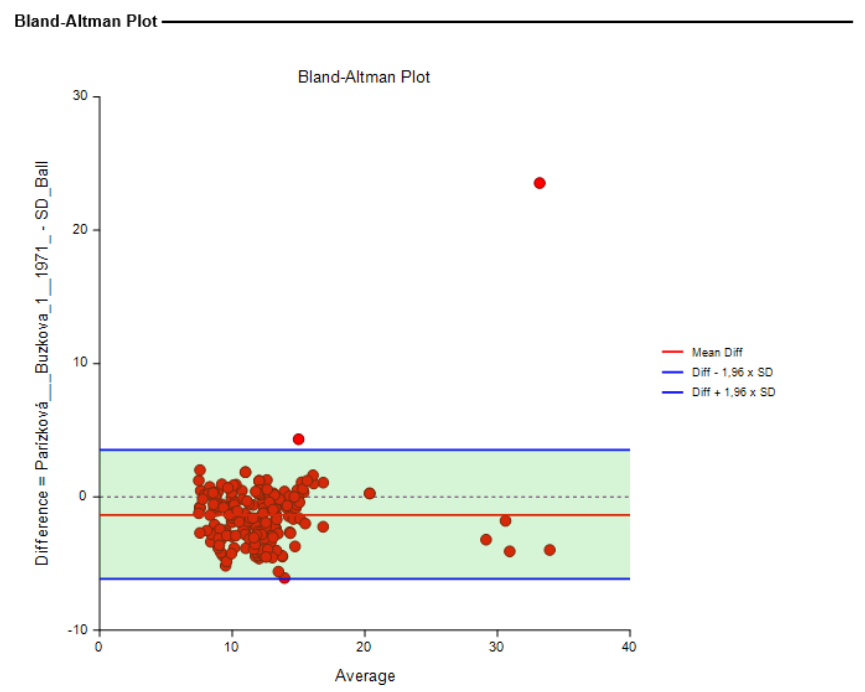

Figure 2. Bland-Altman Plot, Parízková \& Buzková 1 vs. Ball et al. 


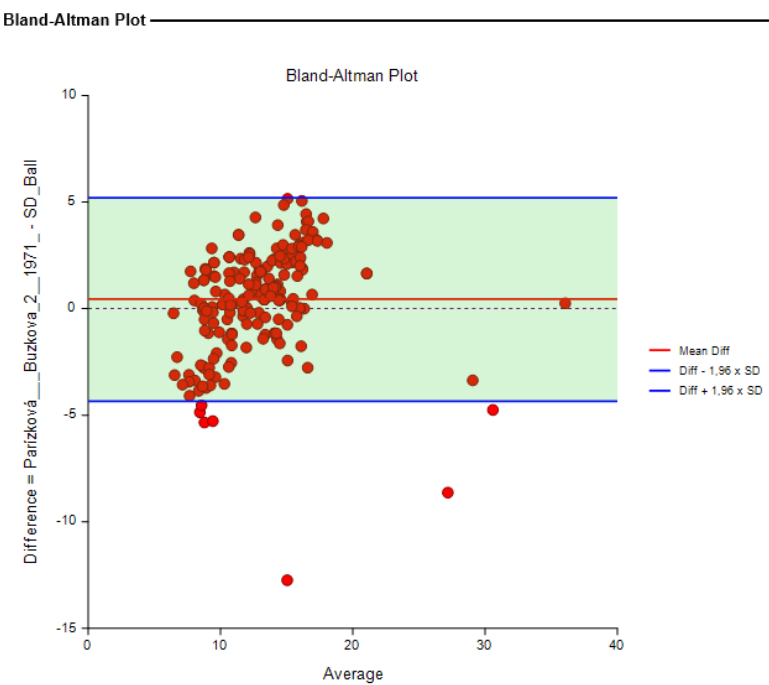

Figure 3. Bland-Altman Plot, Parízková \& Buzkova 2 vs. Ball et al.

The comparison of the regression equations according to Parízková \& Buzková 1 with Parízková \& Buzková 4 has a correlation coefficient of 0.90 . The $t$-test for equivalence gives a p-value of 0.00 . Thus, equivalence is assumed (Fig. 4).

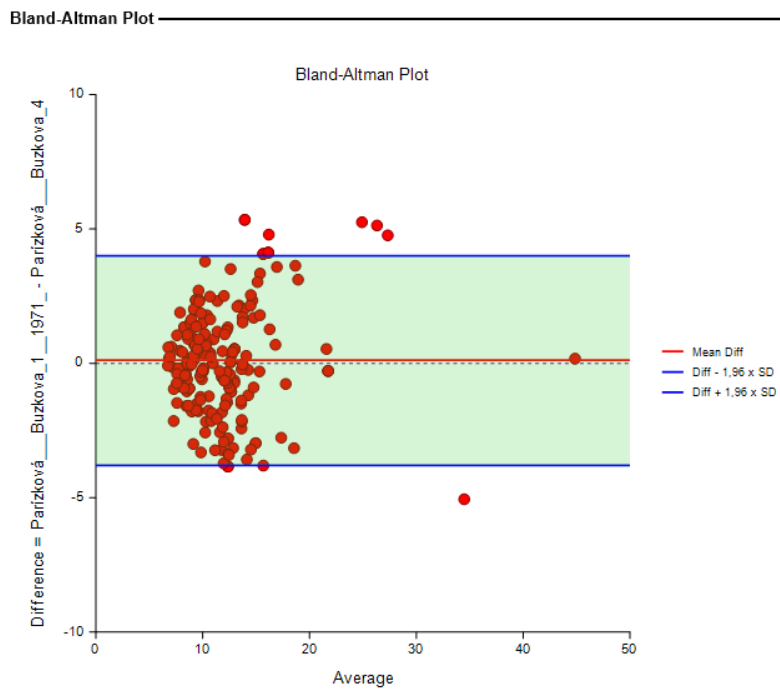

Figure 4. Bland-Altman Plot, Parízková \& Buzková 1 vs. Parízková \& Buzková 4.

The comparison of the regression equations according to Parízková \& Buzková 1 with Parízková \& Buzková 3 has a correlation coefficient of 0.93 . With the exception of a few points, all points are within the confidence limit (Fig. 5). 


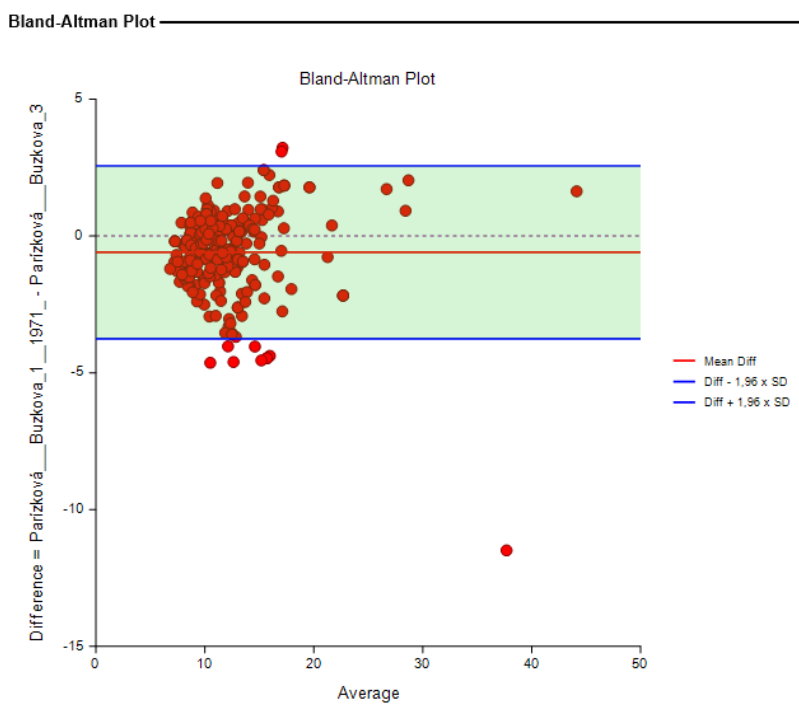

Figure 5. Bland-Altman Plot, Parízková \& Buzková 1 vs. Parízková \& Buzková 3.

The $t$-test for equivalence gives a p-value of 0.00 . Thus, equivalence is assumed. The highest correlation coefficient is the comparison between the regression equations according to Parízková \& Buzková 3 and Parízková \& Buzková 4 with 0.96 (Fig. 6).

The $t$-test for equivalence gives a $\mathrm{p}$-value of 0.00 . Thus, equivalence is assumed.

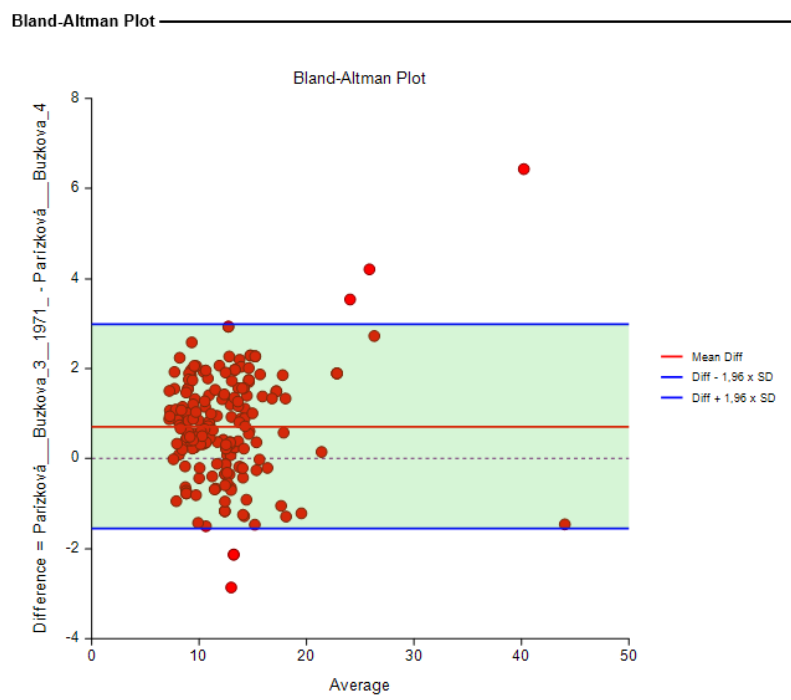

Figure 6. Bland-Altman Plot, Parízková \& Buzková 3 vs. Parízková \& Buzková 4. 
The inter-methodological comparison between infrared reflection measurement and bioelectrical impedance analysis is presented below.

The comparison between infrared reflection measurement and bioelectrical impedance analysis shows that the mean values in the male group are $14.8 \pm 7.3 \%$ and $15.6 \pm 4.9 \%$. The "average of the averages (IR, BIA)" is $15.20 \%$.

The comparison of the mean values of calipermetry, infrared reflection measurement, and bioelectric impedance analysis shows that the mean values of calipermetry were lower than the other two measurement methods.

The comparison between infrared reflection measurement and bioelectrical impedance analysis with respect to the determination of the percentage of body fat percentages shows a relatively low correlation coefficient of $r=0.56$ (Fig. 7).

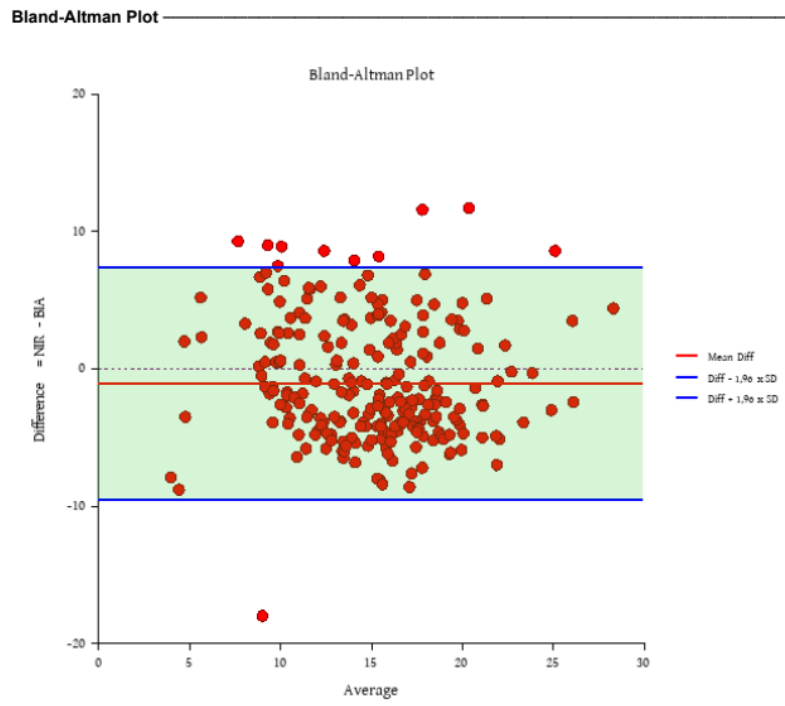

Figure 7. Bland-Altman Plot, BIA vs. IR.

The $t$-test for the test of equivalence gives a p-value of 0.69 . Thus, equivalence is not accepted.

Infrared reflection measurement and bioelectric impedance analysis have a low correlation between each other, but also in comparison to calipermetry $(<0.8)$.

The total body water can only be measured by infrared reflection measurement and bioelectrical impedance analysis. The average values are very close to each other at $50.6 \pm 5.7$ (BIA) and $49.2 \pm 4.9$ (NIR) litres. The correlation coefficient $r=0.91$. (Fig. 8). 


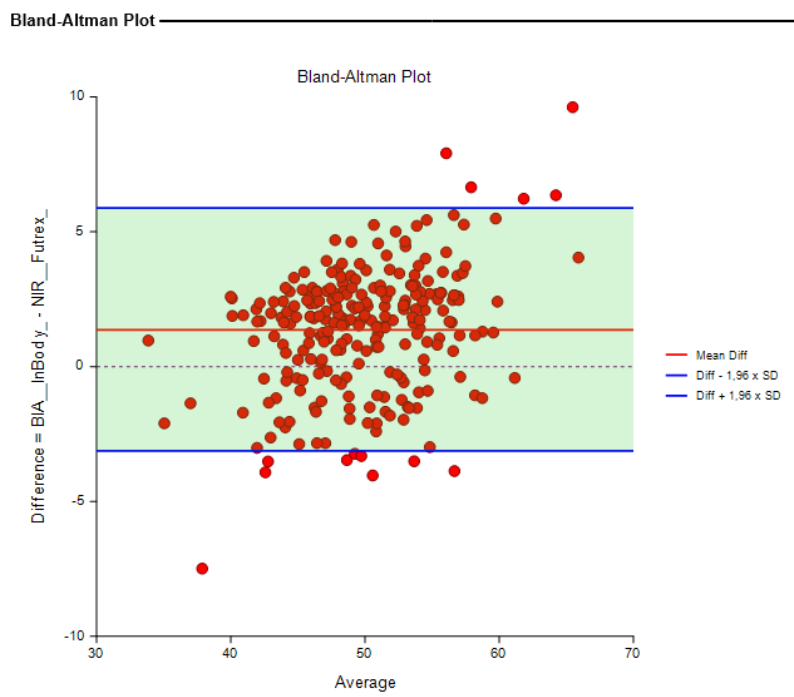

Figure 8. Bland-Altman Plot, Total body water (in L) BIA vs. IR.

The $t$-test for the test of equivalence gives a p-value of 0.99 . Thus, equivalence is not accepted.

\section{DISCUSSION}

The subject of this study was a comparison of measurement methods. All the three measurement methods used have to be purchased. The results of the study showed that with infrared reflection measurement and bioelectrical impedance analysis, a quick, simple body composition analysis is possible. Since many different regression equations were found by calipermetry, but the measurement methodology was considered unpleasant by some people (feeling of embarrassment), it is more advisable for certain study teams to use such methods as infrared reflection measurement or bioelectrical impedance analysis.

Price comparison, on the other hand, would clearly speak in favour of calipermetry. Although the current price for a classic Harpenden Skinfold Caliper ${ }^{\circledR}$ is still $€ 290$, new plastic callipers are now available for $10 \%$ of this sum. A BIA device like the one used in the study costs about $€ 18,000$, the Futrex ${ }^{\circledR}$ body-fat analyser about $€ 4,000$.

Furthermore, conspicuous individual measurement values could also be checked with a second method. 
A significant reason for the prevalence of BIA in hospitals, rehabilitation clinics, fitness and bodybuilding studios, nutrition and sports science institutes and research institutions is certainly the fact that patients, clients or subjects do not need to undress except for the distal limb sections, which also applies to the Futrex ${ }^{\oplus}$ measurement in which only one arm needs to be undressed.

Calipermetry should be carried out by the practice owner, the clinician, the gym's sports doctor or anthropometric specialists.

According to Herm [6], the fat content received by the impedance measurement is up to $6.8 \%$ higher than that of the skin fold measurements. One can only agree with his call for a standardization of impedance measurement and limitation of the variety of devices.

The non-population-specific formula according to Weltman and Katch [19] for determining the percentage of fat used by them (1978) was developed by them in the densitometric comparison of 47 prepuberal children, 22 male and 242 female college visitors, 84 men and 60 middle-aged women.

Ball et al. [1] compared anthropometric equations for determining the percentage of body fat with the DXA method and found very significant correlation coefficients $(\mathrm{p}<0.01)$ in the range between 0.923 and 0.942 in a study collective of 160 men aged $18-62$ years.

As early as in 2003, Herm [6] called for a method-critical examination of BIA and infrared measurement and, as a conclusion, recommended the determination of body fat by means of calipermetry of defined skin folds as a sufficiently reliable and practicable method, while the reliability of the other methods, which at first glance are easy to implement, should be critically questioned.

In a chronobiological study, Raschka et al. [15] compared calipermetry [12] as well as the anthropometric formula according to Weltman and Katch [19], BIA (data input device) and IR for the determination of the percentage of fat content in 24 active subjects. There were significant differences between the different methods, with the lowest values recorded with the Weltman/Katch formula. The IR values and Weltman/Katch data were least affected by ultradian influences.

For the detection of fluid shifts during the day, BIA appears to be the most suitable as a preliminary examination with BIA alone by Dittmar et al. [5] has shown.

Which method for determining the body composition, in particular the percentage of fat, can be replaced by which alternative of determination?

An example is the change of the family doctor (possibly when moving to another city), change of the gym, the coach or the sports medical examination centre. 
How, for example, should a change in the percentage of fat, which perhaps amounted to $14.1 \%$ in the previous year (measured for example with BIA), be interpreted when the fat content is currently $12.1 \%$ at another research site (measured with IR)?

Based on the above results of the examination, the following methods for potential mutual replacement for the following parameters would be suitable in the male sex:

\section{Percentage of fat (calipermetry)}

Parízková \& Buzková 3 [12] and Ball et al. [1]

Parízková \& Buzková 2 [12] and Ball et al. [1]

Parzíková \& Buzková 1 and 4 [12]

Parízková \& Buzková 1 and 3 [12]

Parízková \& Buzková 3 and 4 [12]

2. Percentage of fat and total body water; BIA vs. IR:

There were no significant equivalences.

This would mean that a method exchange of different methods based on divergent measurement principles (e.g., calipermetry vs. BIA vs. INR) is generally not useful and only very specific calipermetric regression equation systems (see above) would be compatible with each other.

\section{REFERENCES}

1. Ball S. D., Altena T. S., Swan P. (2004). Comparison of anthropometry to DXA: A new prediction equation for men. European Journal of Clinical Nutrition, 58 (11), 1525-1531. https://doi.org/10.1038/sj.ejen.1602003

2. Bland J. M., Altman D. G. (1986). Statistical methods for assessing agreement between two methods of clinical measurement. Lancet, 327(8476), 8 Feb 1986, 307-310. https://doi.org/10.1016/S0140-6736(86)90837-8

3. Bland J. M., Altman DG (1999). Measuring agreement in method comparison studies. Stat Methods Med Res, 135-160.

https://doi.org/10.1177/096228029900800204

4. Cowgill G. R. (1957). A formula for estimating the specific gravity of the human body with a consideration of its possible uses. Am J Clinical Nutr, 5, 601-611. https://doi.org/10.1093/ajcn/5.6.601 
5. Dittmar M., Raschka C., Koch H. J. (2002). Effect of diurnal variation on body composition under consideration of selected chronobiological marker systems. Przegląd Antropologiczny - Anthropological Review, 65, 17-26.

6. Herm K. P. (2003). Standards der Sportmedizin: Methoden der Körperfettbestimmung. Deutsche Zeitschrift für Sportmedizin, 54(5), 153-154.

7. Hoffer E., Meador C., Simpson D. (1969). Correlation of whole-body impedance with total body water volume. Journal of Applied Physiology, 27, 531-534. https://doi.org/10.1152/jappl.1969.27.4.531

8. Israel R. G., Houmard J. A., O’Brien K. F., McCammon M. R., Zanora B. S., Eaton A. W. (1989). Validity of a near-infrared spectrophotometry device for estimating human body composition. Journal Research Quarterly for Exercise and Sport, 60(4), 379-383. https://doi.org/10.1080/02701367.1989.10607467

9. Jackson A. S. and Pollock M. L. (1978). Generalized equations for predicting body density of men. Br J Nutr, 40(3), 497-504.

https://doi.org/10.1079/BJN19780152

10. Knußmann R. (1988). Somatometrie. In: Knußmann R. (Hg.) Anthropologie Handbuch der vergleichenden Biologie des Menschen. Bd.I Wesen und Methoden der Anthropologie, pp. 232-285. Stuttgart. New York: Gustav Fischer Verlag.

11. Möhr M., Johnson D. (1972). Tabellen zur Beurteilung des Körpergewichts erwachsener Männer und Frauen nach ihrem Optimalgewicht. Z. ärztl. Fortbildung, 66, 1052-1059.

12. Parízková J, Buzková P (1971). Relationship between skinfold thickness measured by Harpenden Caliper and densitometric analysis of total body fat in men. - A methodological contribution to the International Biological Program. Hum Biol, 43, 16-21.

13. Raschka, C. (2006). Sportanthropologie: Leitfaden der modernen, vergleichenden Sportanthropologie, Sportanthropometrie und trainingsrelevanten Konstitutionsbiologie (1. Auflage). Köln: Sportverlag Strauß.

14. Raschka C. (2016). Körperbau und Körperzusammensetzung. In: Raschka C, Nitsche L.: Praktische Sportmedizin, pp. 45-64. Stuttgart: Thieme-Verlag.

15. Raschka C., Scott V., Dittmar D. (2006). Ultradian comparison of different techniques for assessing body components in athletes - skinfold measurements, circumferences, near infrared interactance, and bioimpedance analysis. Medicina Sportiva, 10(2), 58-62.

16. Rathbun E. N., Pace N., Hinshaw E., Buntin H. (1945). Studies on body composition. 1. The determination of total body fat by means of the body specific gravity. J Biol Chem, 158, 667-676. https://doi.org/10.1016/S0021-9258(19)51343-6

17. Stroh, S. (1995). Methoden zur Erfassung der Körperzusammensetzung. Ernährungsumschau, 42, 88-94. 
18. Tittel K., Wutscherk H. (1972). Sportanthropometrie. Leipzig: Barth.

19. Weltman A., Victor L., Katch V. L. (1978). A Non Population-Specific Method for Predicting Total Body Volume and Percent Fat. Hum Biol, 50(2), 151-158.

\section{Address for correspondence:}

Christoph Raschka

Institute of Sports Sciences

Julius Maximilian University

Judenbühlweg 11, D-97082 Würzburg, Germany

E-mail: christoph.raschka@uni-wuerzburg.de 